\title{
Imidazolines as Non-Classical Bioisosteres of $N$-Acyl Homoserine Lactones and Quorum Sensing Inhibitors
}

\section{Alicia Reyes-Arellano ${ }^{1, *}$, Alejandro Bucio-Cano ${ }^{1}$, Mabel Montenegro-Sustaita ${ }^{1}$, Everardo Curiel-Quesada ${ }^{2}$ and Héctor Salgado-Zamora ${ }^{1}$}

1 Department of Organic Chemistry, National Polytechnic Institute, National School of Biological Sciences, Carpio y Plan de Ayala S/N, Colonia Santo Tomás, 11340 México, D.F., Mexico; E-Mails: abc_pp@hotmail.com (A.B.-C.); mabel_montenegro@hotmail.com (M.M.-S.); hsalgado47@hotmail.com (H.S.-Z.)

2 Department of Biochemistry, National Polytechnic Institute, National School of Biological Sciences, Carpio y Plan de Ayala S/N, Colonia Santo Tomás, 11340 México, D.F., Mexico; E-Mail: ecqmixcoacdf@gmail.com

* Author to whom correspondence should be addressed; E-Mail: areyesarellano@yahoo.com.mx; Tel.: +55-57-29-60-00 ext. 62526; Fax: +55-57-29-60-00 ext. 62526.

Received: 2 November 2011; in revised form: 6 January 2012 / Accepted: 10 January 2012 / Published: 25 January 2012

\begin{abstract}
A series of selected 2-substituted imidazolines were synthesized in moderate to excellent yields by a modification of protocols reported in the literature. They were evaluated as potential non-classical bioisosteres of AHL with the aim of counteracting bacterial pathogenicity. Imidazolines 18a, 18e and $18 \mathrm{f}$ at various concentrations reduced the violacein production by Chromobacterium violaceum, suggesting an anti-quorum sensing profile against Gram-negative bacteria. Imidazoline $\mathbf{1 8 b}$ did not affect the production of violacein, but had a bacteriostatic effect at $100 \mu \mathrm{M}$ and a bactericidal effect at $1 \mathrm{mM}$. Imidazoline 18a bearing a hexyl phenoxy moiety was the most active compound of the series, rendering a $72 \%$ inhibitory effect of quorum sensing at $100 \mu \mathrm{M}$. Imidazoline $18 f$ bearing a phenyl nonamide substituent presented an inhibitory effect on quorum sensing at a very low concentration $(1 \mathrm{nM})$, with a reduction percentage of $28 \%$. This compound showed an irregular performance, decreasing inhibition at concentrations higher than $10 \mu \mathrm{M}$, until reaching $100 \mu \mathrm{M}$, at which concentration it increased the inhibitory effect with a $49 \%$ reduction percentage. When evaluated on Serratia marcescens, compound $18 \mathrm{f}$ inhibited the production of prodigiosin by $40 \%$ at $100 \mu \mathrm{M}$.
\end{abstract}


Keywords: imidazoline synthesis; quorum sensing; Chromobacterium violaceum; AHL bioisosteres

\section{Introduction}

Since the discovery of penicillin by Alexander Fleming in 1928 [1], numerous antibiotics have been introduced for the treatment of once fatal infections, many of which have spread worldwide. At first, the rapid discovery of new antibiotics led to a sufficient drug repertoire that could respond to most antibacterial requirements. However, since then the development of bacterial antibiotic resistance has become a major health issue with multifactorial causes, including the extensive and indiscriminate use of antibiotics, auto-medication, and an increased use of indwelling medical devices [2]. The latter provide a propitious environment for the growth of biofilms [2,3], which are both tenacious and highly resistant to antimicrobial treatment.

The magnitude of the problem demands new strategies. One of the options for overcoming bacterial resistance consists in interrupting a recently discovered pathway of bacterial communication [4-6], termed quorum sensing (QS) [7]. This communication, which regulates a variety of physiological functions, takes place through small peptides in Gram-positive bacteria, and through small molecules, such as $\mathrm{N}$-acyl homoserine lactones (AHL, 1) [4,5], in Gram-negative bacteria. Presumably to avoid alerting the host's immune system to the presence of bacteria, quorum sensing delays virulence factor production until the cell number is high enough such that secretion of virulence factors will result in a productive infection. Therefore, the interruption of quorum sensing in Gram-negative bacteria in order to disable this communication system [2], through the synthesis of bioisosteres [8,9], has become a focus of research.

In the search of new quorum sensing inhibitors against Gram-negative bacteria, AHL has been the lead compound in various studies and different strategies have been adopted. The main structural modifications on AHL to obtain antagonist and agonist bioisosteres may be summarized as follows (Figure 1): (a) Modification of the AHL aliphatic chain mediated by the introduction of an S atom (2) [10], SO group (3) [10], or a ring in the $\Omega$ carbon [11-13] (4, 5); (b) Substitution of the lactone ring $O$ atom by $\mathrm{S}$ [14] (6) or $\mathrm{CH}_{2}$ (7) [15]; and (c) Substitution of the lactone ring by another aliphatic ring (i.e., cyclopentanol, cyclopentanone, cyclohexanol, cyclohexanone, etc.) $(\mathbf{8}, \mathbf{9}, \mathbf{1 0}, \mathbf{1 1})$ [16]. However, in our opinion, all of these transformations imply classical bioisosterism [8,9], and only a few examples of non-classical bioisosteres synthesis have been reported [17,18] (Figure 2). 
Figure 1. Classical bioisosteres of $N$-acyl homoserine lactones (AHL).<smiles>[R]C(=O)CC(=O)NC1C2CCC(C2)C1O</smiles>

$\mathrm{R}=\mathrm{C}_{9} \mathrm{H}_{19}, \mathrm{n}=1 \quad \mathbf{8}$

$\mathrm{R}=\mathrm{C}_{9} \mathrm{H}_{19}, \mathrm{n}=2 \quad \mathbf{1 0}$<smiles>[R]C(=O)CC(=O)NC1C(=O)C2CCC1C2</smiles>

$\mathrm{R}=\mathrm{C}_{9} \mathrm{H}_{19}, \mathrm{n}=1 \quad \mathbf{9}$

$\mathrm{R}=\mathrm{C}_{9} \mathrm{H}_{19}, \mathrm{n}=2 \quad \mathbf{1 1}$<smiles>O=C(NC1CCCC1)NC1CCCC1</smiles>

7<smiles>O=C(CC(=O)NC1CCSC1=O)NC1CC1</smiles>
$\mathrm{n}=2$ o 3

6<smiles>[R]C([R])CC(=O)N([TlH])C1CCOC1=O</smiles>

AHL 1

$\mathrm{R}^{1}=$ Aliphatic chain $\mathrm{R}^{2}=\mathrm{H}, \mathrm{OH},=\mathrm{O}$<smiles>O=C(CSc1cccs1)NC1CCOC1=O</smiles><smiles>O=C(CCc1ccc(Br)cc1F)NC1CCOC1=O</smiles><smiles>O=C(CCCOc1ccc(Cl)cc1)NC1CCOC1=O</smiles>

Figure 2. Non-classical bioisosteres of AHL.<smiles>CCCCNC(=O)CC(=O)Nc1ccccc1O</smiles>

12<smiles>CCCC(=O)CC(=O)Nc1ccccc1C(N)=O</smiles>

13

Other strategies include: (a) Virtual screening of recognized drugs [19] and random screening of compounds synthesized for other purposes [20]; (b) Evaluation of plant extracts, such as the extract of Tremella fuciformis fruiting bodies, which showed quorum sensing inhibitory activity in Chromobacterium violaceum CV026 [21,22]. It is a fact that some positively active antiquorum sensing compounds do not have structural or electronic resemblance with natives AHLs [10,23], Figure 3. 
Figure 3. Compounds with no structural or electronic resemblance to AHLs.

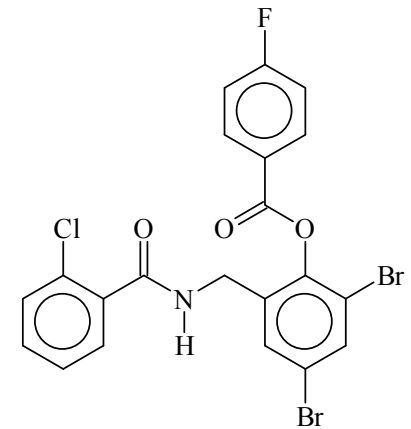

14

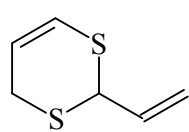

15

The aim of the present work was to investigate a new type of non-classical bioisoster for the acyl homoserine lactone as a possible quorum sensing inhibitor. Therefore six new imidazoline derivatives were selected and evaluated as potential AHL antagonist bioisosteres [8] in the violacein production of Chromobacterium violaceum. Selection of $C$. violaceum, a Gram-negative bacteria, was made considering the fact that the biosynthesis of violacein, violet pigment, is triggered by $n$-hexanoyl-L- $N$-acyl homoserine lactone (C6AHL), quorum sensing dependent [24] and easily detectable by means of spectrophotometry.

\section{Results and Discussion}

\subsection{Bioisosteric Design}

The design of a new type of non-classical bioisosteres consisted of the substitution of the lactone ring in the acyl homoserine lactone by an imidazoline ring, this representing a bioisosteric replacement. The length of the aliphatic chain was not drastically modified, but in four of the compounds the amide functional group was replaced by an ether group. A phenyl ring was introduced to serve as a tether of the imidazoline and the aliphatic chain, with no asymmetric center. As is known, some efficient quorum sensing antagonists lack the asymmetric center [15]. In order to observe the electronic effects on the biological activity of $C$. violaceum, the $O$-aliphatic chain at positions meta and para on the phenyl ring was examined.

\subsection{Chemistry}

The synthesis of the imidazolines was achieved in two steps. In the first stage, the synthetic intermediates 17a-17d were prepared by alkylation of 4-hydroxybenzaldehyde, and the amides $\mathbf{1 7 e}$ and $\mathbf{1 7 f}$ were obtained by reaction of the corresponding carboxylic acids with 4-aminobenzonitrile (Table 1). Cyclization of the required imidazolines 18a-18d was achieved with ethylenediamine and iodine, while imidazolines $\mathbf{1 8 e}$ and $\mathbf{1 8 f}$ were synthesized with ethylenediamine and $\mathrm{CS}_{2}$ using MW (Table 2). 
Table 1. Preparation of synthetic intermediates of imidazoline derivatives.

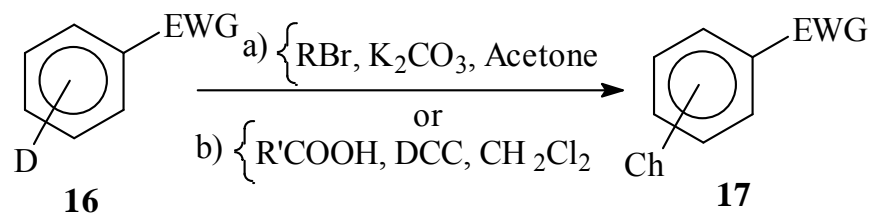

16

$\mathrm{R}, \mathrm{R}^{\prime}=\mathrm{Alkyl}$

\begin{tabular}{|c|c|c|c|c|c|}
\hline D & EWG & $\begin{array}{c}\text { Reagents and } \\
\text { reaction conditions }\end{array}$ & Ch & $\begin{array}{c}\text { Compound } \\
\text { number }\end{array}$ & $\begin{array}{c}\text { Isolated yield } \\
\text { (\%) }\end{array}$ \\
\hline$p-\mathrm{OH}$ & $\mathrm{CHO}$ & a, reflux & $O-\mathrm{nC}_{6} \mathrm{H}_{13}$ & $\mathbf{1 7 a}$ & 80 \\
\hline$p-\mathrm{OH}$ & $\mathrm{CHO}$ & a, reflux & $O-\mathrm{nC}_{9} \mathrm{H}_{19}$ & $\mathbf{1 7 b}$ & 85 \\
\hline$m-\mathrm{OH}$ & $\mathrm{CHO}$ & $\mathrm{a}$, reflux & $O-\mathrm{nC}_{6} \mathrm{H}_{13}$ & $\mathbf{1 7 c}$ & 81 \\
\hline$m-\mathrm{OH}$ & $\mathrm{CHO}$ & a, reflux & $O-\mathrm{nC}_{9} \mathrm{H}_{19}$ & $\mathbf{1 7 d}$ & 81 \\
\hline $\mathrm{NH}_{2}$ & $\mathrm{CN}$ & b, r.t. & $\mathrm{NHCO}-\mathrm{nC}_{5} \mathrm{H}_{11}$ & $\mathbf{1 7 e}$ & 70 \\
\hline $\mathrm{NH}_{2}$ & $\mathrm{CN}$ & b, r.t. & $\mathrm{NHCO}-\mathrm{nC}_{8} \mathrm{H}_{17}$ & $\mathbf{1 7 f}$ & 80 \\
\hline
\end{tabular}

Table 2. Synthesis of the 2-arylimidazoline derivatives.

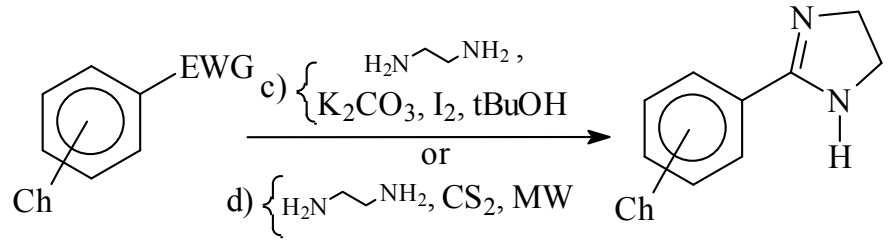

17 18

\begin{tabular}{|c|c|c|c|c|}
\hline Ch & EWG & $\begin{array}{c}\text { Reagents and } \\
\text { conditions }\end{array}$ & $\begin{array}{c}\text { Compound } \\
\text { number }\end{array}$ & $\begin{array}{c}\text { Isolated yield } \\
\text { (\%) }\end{array}$ \\
\hline$p-O-\mathrm{nC}_{6} \mathrm{H}_{13}$ & $\mathrm{CHO}$ & $\mathrm{c}$, reflux & $\mathbf{1 8 a}$ & Quantitative \\
\hline$p-O-\mathrm{nC}_{9} \mathrm{H}_{19}$ & $\mathrm{CHO}$ & $\mathrm{c}$, reflux & $\mathbf{1 8 b}$ & Quantitative \\
\hline$m-O-\mathrm{nC}_{6} \mathrm{H}_{13}$ & $\mathrm{CHO}$ & $\mathrm{c}$, reflux & $\mathbf{1 8 c}$ & Quantitative \\
\hline$m-O-\mathrm{nC}_{9} \mathrm{H}_{19}$ & $\mathrm{CHO}$ & $\mathrm{c}$, reflux & $\mathbf{1 8 d}$ & Quantitative \\
\hline $\mathrm{NHCO}-\mathrm{nC}_{5} \mathrm{H}_{11}$ & $\mathrm{CN}$ & $\mathrm{d}, \mathrm{MW}$ & $\mathbf{1 8 e}$ & 50 \\
\hline $\mathrm{NHCO}-\mathrm{nC}_{8} \mathrm{H}_{17}$ & $\mathrm{CN}$ & $\mathrm{d}, \mathrm{MW}$ & $\mathbf{1 8 f}$ & 60 \\
\hline
\end{tabular}

Synthetic intermediates 17a-17d were prepared [25] in good yields. Amide derivative 17e is commercially available, but both 17e and 17f were prepared using MW as a source of energy in an adaptation of the methodology described in the literature [26].

Imidazoline derivative 18a has been previously prepared in $75 \%$ yield using the corresponding alkyloxybenzonitrile and inner salt $p-\mathrm{CH}_{3}-\mathrm{C}_{6} \mathrm{H}_{4} \mathrm{SO}_{3} \mathrm{H}_{3} \mathrm{NCH}_{2} \mathrm{CH}_{2} \mathrm{NH}_{2}$ [27]. Imidazoline derivative 18b was prepared in $29 \%$ yield [28]. In contrast, these compounds and the new ones 18c-18d were successfully prepared by us in quantitative yields via an adaptation of the protocol described by Fujioka [29]. Imidazoline derivatives 18e and $\mathbf{1 8 f}$ were synthesized in moderate yields by an adaptation of a procedure described in the literature [30]. All compounds were characterized by spectroscopic methods. The spectroscopy of known compounds in the present work was in agreement with that reported in the literature [28,31,32].

It is worth mentioning that imidazolines $\mathbf{1 8 a}$ and $\mathbf{1 8 b}$ were evaluated as monoxidase inhibitors with antidepressant activity, but were not highly active [28]. Imidazoline 18a was evaluated unsuccessfully 
as an antituberculous agent [27]. However, none of these compounds have been evaluated as quorum sensing inhibitors.

\subsection{Biology}

\subsubsection{Evaluation of the Imidazoline Derivatives 18a-18f on Chromobacterium violaceum wt.}

Bioisosteres of the $N$-acyl homoserine lactone, 18a-18f were evaluated at concentrations between $100 \mathrm{pM}$ and $100 \mu \mathrm{M}$ (Figure 4). Imidazoline 18a had an effect on the production of violacein only at a concentration of $100 \mu \mathrm{M}$, without affecting the growth of the bacteria. Concentrations of 25, 50, 75, 90 and $100 \mu \mathrm{M}$ of compound 18a were tested in order to calculate the IC50 value, which turned out to be $90.9 \mu \mathrm{M}$. This compound also inhibited bacteria growth at higher concentrations (data not shown). Compound 18b did not affect the production of violacein, but it had a bacteriostatic effect at $100 \mu \mathrm{M}$ and a bactericidal effect at a $1 \mathrm{mM}$ concentration (data for the latter is not shown). The graph (Figure 4) shows an apparent inhibition between the concentrations $0.1 \mathrm{nM}$ and $0.1 \mu \mathrm{M}$, but this effect was not statistically significant. Compounds 18c and 18d did not have any effect on violacein production in the time period and concentrations employed in the evaluation, except for the growth inhibition exerted by compound 18d at a concentration of $100 \mu \mathrm{M}$. Bioisoster $\mathbf{1 8 f}$ showed an inhibitory effect on violacein production starting at a concentration of $1 \mathrm{nM}$, showing an irregular performance where the highest inhibition, 49\%, was observed at $100 \mu \mathrm{M}$ (Figure 4). Compound 18e showed a bimodal behavior, with an inhibitory effect only at $0.1 \mu \mathrm{M}$ and $1 \mu \mathrm{M}$.

Figure 4. Evaluation of activity of imidazolines 18a-18f in violacein production on C. violaceum. Effect of biososteres in violacein production in C. violaceum. Blank control (brown), 18a (red), 18b (green), 18c (black), 18d (cyan), 18e (violet) and 18f (blue). Asterisks indicate statistically significant activity. Data were calculated by using a two way ANOVA test with Duncan correction and are displayed as the mean $\pm \mathrm{SE}(n=6)$.

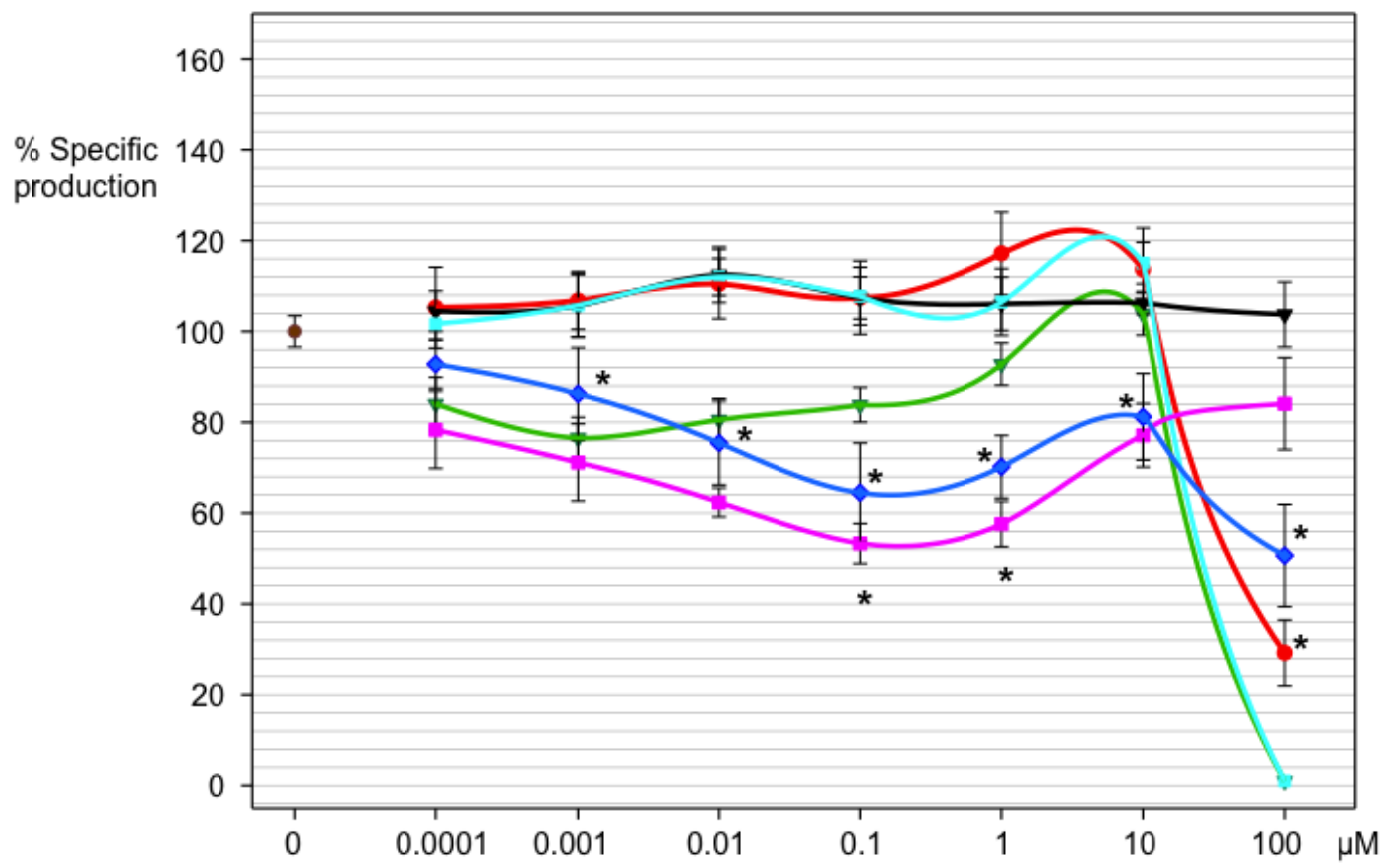




\subsubsection{Effect of Compounds $\mathbf{1 8 a}-\mathbf{1 8 f}$ on the Viability of Chromobacterium violaceum Wild Type}

A viable count was made of those cultures that showed inhibition of pigment production in presence of the imidazolines under study, using the concentrations at which such activity was observed. After the evaluation, it was found that the number of CFU was without change compared with the respective control group. This clearly indicated that the inhibitory effect on the production of violacein is not due to a decrease in the number of bacteria, but instead to the effects of the test compounds.

\subsubsection{Effects of the Imidazoline Derivatives on Chromobacterium violaceum}

Compounds 18a, 18e and $\mathbf{1 8 f}$ showed an inhibitory effect on quorum sensing, evidenced by the reduction in violacein production. This was confirmed by the viable count, which showed that the number of CFU was without change compared with the respective control group. Compounds 18e and 18f gave a linear response only at initial concentrations of $0.0001-0.1 \mu \mathrm{M}$. At higher concentrations, the activity was lost or reduced, suggesting that the inhibition depends on the concentration and structure of the compound. Neither 18e nor $18 \mathrm{f}$ reached a $50 \%$ inhibition under the range of concentrations tested. Although the causes of this behavior are unknown, it is possible that bioisosteres stimulate the production of the pigment at high concentrations either by inducing compensatory conformational changes in the CviR receptor, or in an indirect way, such as by stimulating the synthesis of dye precursors. A non-linear event in $Q S$ evaluation of certain compounds was also observed by Martinelli and collaborators [33]. They evaluated several furanones, bioisosteres of the furanones of Delisea pulchra, as inhibitors of the production of violacein. Martinelli concluded that the same compound may be an activator or inhibitor.

With compound 18a, which has an ether moiety in the connector, inhibitory activity could have been the result of the imidazoline group acting as a bioisoster of the lactone ring, and the electronic conjugation of the ether with the imidazoline, conferring the latter nucleus a more basic character. Indeed, it is known that the production of violaceine is sensible to the basicity [23]. However, it is clear that basicity is not the only important feature, since imidazoline $\mathbf{1 8 b}$, with similar electronic properties, did not present a statistically significant anti-quorum sensing activity.

The imidazolines that have the ether group at the meta position (18c and 18d) in the connector did not present inhibitory activity on the production of violacein, which supports the importance of the electronic conjugation. The anti-quorum sensing activity shown by the compounds $\mathbf{1 8 e}$ and $\mathbf{1 8 f}$ confirms that the imidazoline ring acts as a bioisoster of the lactone ring. In this case we consider that factors like the conservation of the amide group, the length of the chain, and the conjugation between the amide moiety and the imidazoline group contributed to the activity obtained. Remarkably, compound $\mathbf{1 8 f}$ showed initial activity at the lowest concentration so far reported to inhibit C. violaceum $\mathrm{QS}, 1 \mathrm{nM}$.

Compound $18 \mathrm{f}$ was more active than the more promising 18e, which contains the same chain length as the acyl group in the natural AHL. Williams [34] found that as the aliphatic chain length in the majority of the AHL of Gram-negative bacteria increases, the compounds change from activators to inhibitors on the production of violacein. 
The antiquorum sensing activity of imidazolines 18a, 18e and $18 \mathrm{f}$ can be compared with other reports in the literature. Imidazoline 18a, which showed the highest antiquorum sensing activity of all bioisosteres tested in this work (at $100 \mu \mathrm{M}$ ), rendered $71 \%$ inhibition. In contrast, 2-(4'-chlorophenoxy)- $N$-butanoyl homoserine lactone 4, which is claimed to be the most active analog of AHL synthesized so far [11], gave a total inhibition of violacein at $10^{-4} \mathrm{M}$. The activity of compound 18a could also be compared with some furanones, which at a concentration of $10^{-4} \mathrm{M}$ showed an inhibition at around 95\%, as reported by Martinelli [33].

Imidazoline 18e showed the initial inhibition of QS at $0.1 \mu \mathrm{M}(100 \mathrm{nM})$, rendering a $47 \%$ inhibition. At $1 \mu \mathrm{M}$ this same compound yielded a $42 \%$ inhibition of the dye. By contrast, $\mathrm{N}$-decanoyl-L-homoserine lactone (DHL) was the most active compound of a reported series of acyl homoserine lactones, showing a 51\% inhibition of the dye at $100 \mathrm{nM}$ [34]. Meanwhile, imidazoline 18f showed the initial inhibition at $1 \mathrm{nM}$ (the lowest concentration of this series), resulting in a $14 \%$ inhibition of QS, and at $100 \mu \mathrm{M}$ rendered a $49 \%$ inhibition.

To summarize, imidazoline $\mathbf{1 8 f}$ shows initial inhibitory activity of $Q S$ at a very low concentration $(1 \mathrm{nM})$, and its highest activity (49\% inhibition) at $100 \mu \mathrm{M}$. On the other hand, imidazoline 18a shows the highest activity (71\% inhibition) of this series at $100 \mu \mathrm{M}$. Thus, imidazoline 18a and 18f are very promising lead compounds for further research. Current structural modifications on 18a and 18f are under way to improve the anti $Q S$ activity.

\subsubsection{Evaluation of $N$-[4-Phenyl-(imidazo-2-yl)]-nonamide on Serratia marcescens ATCC 8100}

Due to the activity of compound $\mathbf{1 8 f}$ on the production of violacein in Chromobacterium violaceum, this compound was evaluated on Serratia marcescens, a pathogenic Gram-negative bacteria found in nosocomial infections [35]. Serratia marcescens uses several types of signaling molecules with the $\mathrm{N}$-acyl homoserine lactone core [36] for the synthesis of prodigiosin, a red dye that is regulated in a QS-dependent manner (Figure 5).

Figure 5. $N$-Acyl homoserine lactones utilized in quorum sensing by Serratia marcescens.

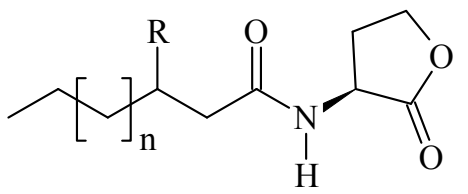

$$
\begin{aligned}
& \mathrm{R}=\mathrm{H} \quad \mathrm{n}=1 \\
& \mathrm{R}=\mathrm{O} \quad \mathrm{n}=1 \\
& \mathrm{R}=\mathrm{H} \quad \mathrm{n}=2 \\
& \mathrm{R}=\mathrm{H} \quad \mathrm{n}=3
\end{aligned}
$$

Compound 18f inhibited the production of prodigiosin at practically every concentration tested (Figure 6). At $10 \mu \mathrm{M}$ it inhibited $20 \%$ of the dye production and at $100 \mu \mathrm{M}$ inhibited $40 \%$. When testing other concentrations $(50,150,200,250$ and $300 \mu \mathrm{M})$ of compound 18f, the IC50 was found to be $106.5 \mu \mathrm{M}$. The inhibition of prodigiosin by $\mathbf{1 8 f}$ was $15.7 \%$ at a concentration of $50 \mu \mathrm{M}, 51.6 \%$ at $150 \mu \mathrm{M}, 55.8 \%$ at $200 \mu \mathrm{M}, 56.3 \%$ at $250 \mu \mathrm{M}$, and $64.8 \%$ at $300 \mu \mathrm{M}$. The growth of the bacteria was not affected in any case. In contrast $10 \mu \mathrm{M}$ of nonanoyl cyclopentyl amide (7) rendered only $10 \%$ of prodigiosin inhibition, and $200 \mu \mathrm{M}$ gave $85 \%$ [15]. 
Figure 6. Evaluation of activity of imidazoline 18f on Serratia marcescens. Data were analyzed employing the two way ANOVA test with Duncan correction, and are displayed as the mean $\pm \operatorname{SE}(n=6)$.

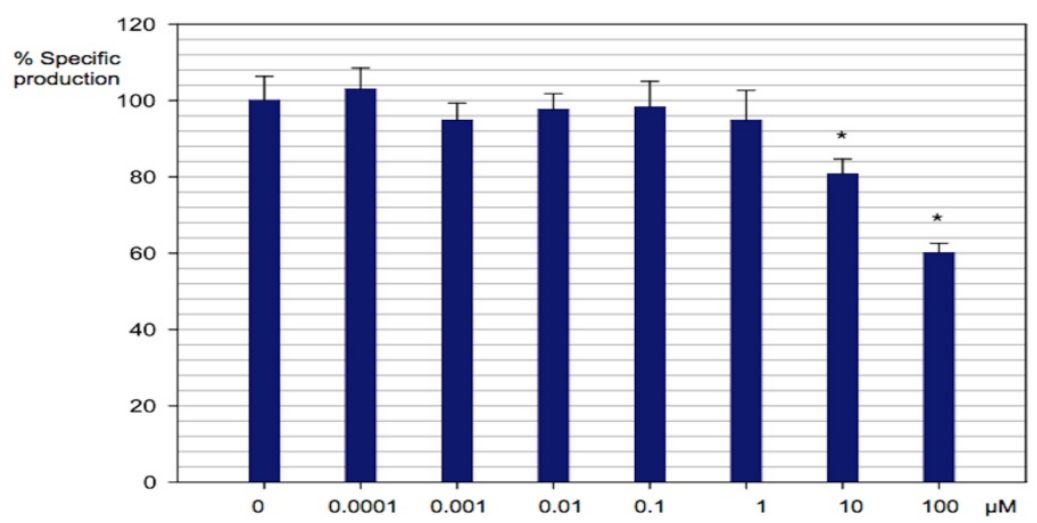

\section{Experimental Section}

\subsection{Experimental Chemical Section}

Melting points were determined on an Electrothermal melting point apparatus and are uncorrected. Infrared spectra were recorded on a Perkin Elmer 599-B spectrophotometer. NMR spectra were recorded with a Varian Mercury $300 \mathrm{MHz}$ or NMR on a Varian 500 spectrometer.

The chemical shifts $(\delta)$ are referenced to internal $\left(\mathrm{CH}_{3}\right)_{4} \mathrm{Si}\left(\delta^{1} \mathrm{H}=0, \delta^{13} \mathrm{C}=0\right)$. The electron ionization (EI) mass spectra $(70 \mathrm{eV})$ were recorded using a Hewlett Packard HP-5998A spectrometer. HRMS was determined using a JEOL-JSM-GC mateII.

$p$-Hydroxybenzaldehyde, benzonitrile and other compounds used to synthesis were purchased from Sigma-Aldrich and used without further purification except ethylenediamine, which was distillated over sodium.

\subsubsection{General Procedure for the Synthesis of 4-Alkyloxybenzaldehydes [25]}

To a solution of 1.0 equivalent (eq) of the corresponding hydroxybenzaldehyde in acetone, $\mathrm{K}_{2} \mathrm{CO}_{3}$ (1.5 eq) was added and the mixture stirred for $1 \mathrm{~h}$ at $40{ }^{\circ} \mathrm{C}$. Then $1.1 \mathrm{eq}$ of the corresponding alkylhalide was added and the mixture was refluxed for $15 \mathrm{~h}$ under constant stirring. Progress of the reaction was monitored by TLC (hexane:EtOAc 8:2). Water was added to the reaction mixture and extracted with ether $(3 \times 20 \mathrm{~mL})$. The organic extracts were combined and washed with $5 \% \mathrm{NaCl}$ solution, dried over $\mathrm{Na}_{2} \mathrm{SO}_{4}$ anh. and the solvent removed under vacuum to dryness. The crude product was purified by chromatography on $\mathrm{SiO}_{2}$ using a gradient of a mixture hexane:EtOAc, giving the pure compounds as a colorless oil. The purified compounds were further characterized by common spectroscopic methods.

4-Hexyloxybenzaldehyde (17a) [31]. IR (KBr): $v=2931 \mathrm{~cm}^{-1}, 2858,2734,1695,832 ;{ }^{1} \mathrm{H}$ NMR $\left(\mathrm{CDCl}_{3}\right): \delta=9.86(\mathrm{~s}, 1 \mathrm{H}, \mathrm{CHO}), 7.40\left(\mathrm{AA}^{\prime} \mathrm{BB}^{\prime}, 4 \mathrm{H}, \mathrm{Ph}\right), 4.02\left(\mathrm{t}, 2 \mathrm{H}, \mathrm{OCH}_{2}\right), 1.82(\mathrm{~m}, 2 \mathrm{H}, \mathrm{H}-7)$, 1.35 (m, 6H, H-8, H-9, H-10), $0.91\left(\mathrm{t}, 3 \mathrm{H}, \mathrm{CH}_{3}\right) ;{ }^{13} \mathrm{C}$ NMR $\left(\mathrm{CDCl}_{3}\right): \delta=190.6(\mathrm{CHO}), 164.1(\mathrm{C}-5)$, 
131.8 (C-3), 129.5 (C-2), 114.6 (C-4), 68.2 (C-6), 31.1 (C-7), 28.9 (C-8), 25.5 (C-9), 22.4 (C-10), $13.9(\mathrm{C}-11)$.

4-Nonyloxybenzaldehyde (17b) [32]. IR (KBr): $v=2989 \mathrm{~cm}^{-1}, 2868,2736,1694,830 ;{ }^{1} \mathrm{H}$ NMR $\left(\mathrm{CDCl}_{3}\right): \delta=9.90(\mathrm{~s}, 1 \mathrm{H} \mathrm{CHO}), 7.38\left(\mathrm{AA}^{\prime} \mathrm{BB}^{\prime} 4 \mathrm{H}, \mathrm{Ph}\right), 4.0$ (t, 2H, H-6), 1.79 (m, 2H, H-7), 1.27 (m, 12H, H-8, H-9, H-10, H-11, H-12, H-13), 0.88 (t, 3H, $\left.\mathrm{CH}_{3}\right) ;{ }^{13} \mathrm{C}$ NMR $\left(\mathrm{CDCl}_{3}\right): \delta=190.3$ (CHO), 164.0 (C-5), 131.7 (C-3), 129.5 (C-2), 114.5 (C-4), 68.1 (C-6), 31.7 (C-7), 29.3 (C-8), 29.2 (C-9), 29.1 (C-10), 28.9 (C-11), 25.8 (C-12), 22.5 (C-13), 13.9 (C-14).

\subsubsection{General Procedure for the Synthesis of 3-Alkylbenzaldehydes}

In a pressure tube were added 1.0 eq of 3-hydroxy benzaldehyde, 2 eq of $\mathrm{K}_{2} \mathrm{CO}_{3}$ and THF, and then 2.0 eq of triethylamine and $1.1 \mathrm{eq}$ of alkylbromide. The reaction mixture was stirred and heated at $120{ }^{\circ} \mathrm{C}$ for $10 \mathrm{~h}$ ( $\mathrm{TLC} \mathrm{SiO}_{2}$ hexane:EtOAc 8:2). The reaction was cooled to r.t., water was added and extracted with ether 5 times. The organic phases were washed with $5 \% \mathrm{NaCl}$ and dried over $\mathrm{Na}_{2} \mathrm{SO}_{4}$ anh. The solvent was removed by a rotary evaporator. The crude products were purified by chromatography on silica gel (hexane:AcOEt gradient). The pure compounds were characterized by common spectroscopic methods.

3-Hexyloxybenzaldehyde (17c). IR (KBr): $v=2931 \mathrm{~cm}^{-1}, 2858,2725,1698,1263,785 ;{ }^{1} \mathrm{H}$ NMR $\left(\mathrm{CDCl}_{3}\right): \delta=9.98(\mathrm{~s}, 1 \mathrm{H}, \mathrm{CHO}), 7.44$ (d, 2H, H-3, H-6), 7.43 (dd, 1H, H-7), 7.38 (dd, 1H, H-5), 4.0 (t, 2H, H-8), 1.80 (dt, 2H, H-9), 1.47 (m, 2H, H-10), 1.35 (m, 4H, H-11, H-12), 0.91 (t, 3H, $\left.\mathrm{CH}_{3}\right) ;{ }^{13} \mathrm{C}$ NMR $\left(\mathrm{CDCl}_{3}\right): \delta=192.2$ (CHO), 159.6 (C-4), 137.78 (C-2), 129.9 (C-6), 123.3 (C-7), 121.9 (C-5), 112.6 (C-3), 68.2 (C-8), 31.5 (C-9), 29.0 (C-10), 25.6 (C-11), 22.6 (C-12), 14.0 (C-13).

3-Nonyloxybenzaldehyde (17d). IR (KBr): $v=3068 \mathrm{~cm}^{-1}, 2925,2854,2724,1701,1262,786 ;{ }^{1} \mathrm{H}$ NMR $\left(\mathrm{CDCl}_{3}\right): \delta=9.93$ (s, 1H, CHO), 7.40 (d, 2H, H-3, H-6), 7.36 (dd, 1H, H-7), 7.15 (dd, 1H, H-5), 3.97 (t, 2H, H-8), 1.79 (dt, 2H, H-9), 1.44 (m, 2H, H-10), 1.26 (m, 10H, H-11, H-12, H-13, H-14, $\mathrm{H}-15), 0.86$ (t, 3H, $\left.\mathrm{CH}_{3}\right) ;{ }^{13} \mathrm{C} \mathrm{NMR}\left(\mathrm{CDCl}_{3}\right): \delta=192.0(\mathrm{CHO}), 159.6(\mathrm{C}-4), 137.6$ (C-2), $129.8(\mathrm{C}-6)$, 123.1 (C-7), 121.8 (C-5), 112.6 (C-3), 68.1 (C-8), 31.8 (C-9), 29.4 (C-10), 29.3 (C-11), 29.2 (C-12), 29.0 (C-13) 25.9 (C-14), 22.6 (C-15), 14.0 (C-16).

\subsubsection{General Procedure for the Synthesis of Imidazolines from Benzaldehydes}

To 1 eq of alkyloxybenzaldehyde dissolved in $t$-BuOH was added 1.1 eq of ethylenediamine, at r.t. under $\mathrm{N}_{2}$ atmosphere and with constant stirring. The reaction mixture was held under these conditions for $1 \mathrm{~h}$, then 1.25 eq of $\mathrm{I}_{2}$ and 3 eq of $\mathrm{K}_{2} \mathrm{CO}_{3}$ were added. The resulting mixture was stirred at $70{ }^{\circ} \mathrm{C}$ for $3 \mathrm{~h}$. Then the mixture was filtered and the residue was poured in water and extracted with EtOAc 5 times. The organic phase was washed with a saturated solution of $\mathrm{Na}_{2} \mathrm{SO}_{3}$ and dried over $\mathrm{Na}_{2} \mathrm{SO}_{4}$ anh. The solvent was evaporated in a rotatory evaporator and the remnant residue was purified by chromatography on neutral $\mathrm{Al}_{2} \mathrm{O}_{3}$ (hexane:EtOAc gradient) to furnish the pure compounds.

8-Hexyloxyphenyl-2-imidazoline (18a). m.p. $120-121{ }^{\circ} \mathrm{C}$ (hexane:EtOAc 1:1); Lit. [27,28] $124{ }^{\circ} \mathrm{C}$, 122-123 ${ }^{\circ} \mathrm{C}$ (acetone:hexane); IR (KBr): $v=3084 \mathrm{~cm}^{-1}, 2929,1615,1513,841,741$; ${ }^{1} \mathrm{H}$ NMR (DMSO-d $)_{6}$ ): $\delta=7.59$ (AA'BB', 4H, Ph), 4.07 (t, 2H, H-9), 3.91 (s, 4H, H-4, H-4'), 1.73 (qi, 2H, H-10), 
1.42 (m, 2H, H-11), 1.31 (m, 4H, H-12, H-13), 0.88 (t, 3H, CH $) ;{ }^{13} \mathrm{C}$ NMR (DMSO-d $): \delta=163.8$ (C-2), 162.9 (C-8), 130.6 (C-6), 115.0 (C-5), 114.7 (C-7), 68.0 (C-9), 44.8 (C-4, C-4'), 30.9 (C10),

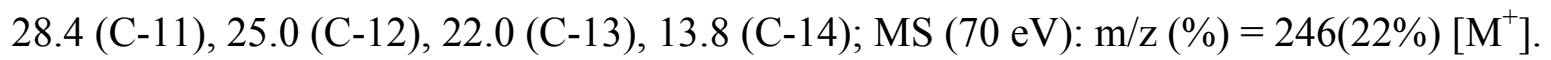

8-Nonyloxyphenyl-2-imidazoline (18b). m.p. $\quad$ 107-108 $\quad{ }^{\circ} \mathrm{C} \quad$ (EtOAc:acetone 8:2), Lit. [28] 108-108.5 ${ }^{\circ} \mathrm{C}$; IR (KBr): $v=3217 \mathrm{~cm}^{-1}, 2922,1618,1246,828 ;{ }^{1} \mathrm{H}$ NMR (DMSO-d $): \delta=6.55$ (AA'BB', 4H, Ph), 3.22 (t, 2H, H-9), 2.78 (s, 4H, H-4, H-4'), 0.90 (qi, 2H, H-10), 0.49 (m, 10H, H-11, H-12, H-13, H-14, H-15), 0.10 (t, 3H, $\left.\mathrm{CH}_{3}\right) ;{ }^{13} \mathrm{C}$ NMR (DMSO-d $\left.{ }_{6}\right): \delta=163.1(\mathrm{C}-2)$, 160.1 (C-8), 128.5 (C-6), 122.8 (C-5), 113.8 (C-7), 67.4 (C-9), 49.4 (C-4, C-4'), 31.2 (C10), 28.9 (C-11), 28.7 (C-12), 28.6 (C-13), 28.5 (C-14), 25.4 (C-15), 22.0 (C-16), 13.9 (C-17); HRMS $=\mathrm{C}_{18} \mathrm{H}_{28} \mathrm{ON}_{2}$ Calcd.: 288.2202, found 288.2201.

7-Hexyloxyphenyl-2-imidazoline (18c). m.p. $=88-89 \quad{ }^{\circ} \mathrm{C} \quad$ (hexane:EtOAc 6:4); IR (KBr): $v=3177 \mathrm{~cm}^{-1}(\mathrm{NH}), 2919,2853,1614,1276,851 ;{ }^{1} \mathrm{H}$ NMR (DMSO-d $\left.6, \mathrm{CDCl}_{3}\right): \delta=7.37(\mathrm{~m}, 1 \mathrm{H}$, H-10), 7.29 (m, 2H, H9, H-6), 6.98 (ddd, $\left.J_{8,9}=3.0 \mathrm{~Hz}, J_{8,6}=8 \mathrm{~Hz}, J_{8.9}=9.0 \mathrm{~Hz}, 1 \mathrm{H}, \mathrm{H}-8\right), 3.96$ (t, $J=6.0 \mathrm{~Hz}$ ) 2H, H-11), 3.78 (s, 4H, H-4, H-4'), 1.76 (m, 2H, H-12), 1.43 (m, 2H, H-13), 1.33 (m, 4H, $\mathrm{H}-14, \mathrm{H}-15) 0.89$ (t, 3H, CH 3 ); ${ }^{13} \mathrm{C}$ NMR (DMSO-d $\left.6, \mathrm{CDCl}_{3}\right): \delta=164.8$ (C-2), 159.2, (C-7), 131.7 (C-5), 129.4 (C-9), 118.9 (C-10), 117.8 (C-8), 112.3 (C-6), 68.1 (C-11), 31.5 (C-4), 30.9 (C-12), 29.2(C-13), 25.6(C-14), 22.6 (C-15), 13.1 (C-16); HRMS = $\mathrm{C}_{15} \mathrm{H}_{22} \mathrm{~N}_{2} \mathrm{O}$ Calcd.: 246.1716, found: 246.1732 .

7-Nonyloxyphenyl-2-imidazoline (18d). m.p. 82-83 ${ }^{\circ} \mathrm{C}$ (H:AcOEt 6:4); IR (KBr): $v=3053 \mathrm{~cm}^{-1}, 2926$, 2854, 1615, 1265, 739; ${ }^{1} \mathrm{H}$ NMR (Acetone-d ${ }_{6} \mathrm{CDCl}_{3}$ ): $\delta=7.35$ (ddd, $J_{10,9}=0.5 \mathrm{~Hz}, J_{10,6}=1.0 \mathrm{~Hz}$, $\left.J_{10,8}=2.6 \mathrm{~Hz}, 1 \mathrm{H}, \mathrm{H}-10\right) ; 7.272\left(\mathrm{dd}, J_{10,9}=0.5 \mathrm{~Hz}, J_{8,9}=6.0 \mathrm{~Hz}, 1 \mathrm{H}, \mathrm{H}-9\right), 7.268$ (dd, $J_{10,6}=1.0 \mathrm{~Hz}$, $\left.J_{6,8}=3.4 \mathrm{~Hz}, 1 \mathrm{H}, \mathrm{H}-6\right), 6.97\left(\mathrm{ddd}, J_{8,10}=2.6 \mathrm{~Hz}, J_{8,9}=6.0 \mathrm{~Hz}, J_{6,8}=3.4 \mathrm{~Hz}, 1 \mathrm{H}, \mathrm{H}-8\right), 4.01(\mathrm{t}, 2 \mathrm{H}$, H-11), 3.66 (s, 4H, H-4, H-4'), 1.78 (m, 2H, H-12), 1.32 (m, 2H, H-13), 1.29 (m, 10H, H-14, H-15, $\mathrm{H}-16, \mathrm{H}-17, \mathrm{H}-18), 0.88\left(\mathrm{t}, 3 \mathrm{H}, \mathrm{CH}_{3}\right) ;{ }^{13} \mathrm{C} \mathrm{NMR}$ (Acetone-d $\left.{ }_{6} \mathrm{CDCl}_{3}\right): \delta=163.1(\mathrm{C}-2), 158.0,(\mathrm{C}-7)$, 131.3 (C-5), 128.0 (C-9), 118.1 (C-10), 115.6 (C-8), 111.6 (C-6), 66.6 (C-11), 52.9 (C-4), 48.9 (C-12, C-13), 30.6 (C-14), 28.3 (C-15), 28.0 (C-16), 24.8 (C-17), 21.3 (C-18), 12.4(C-19); HRMS $=\mathrm{C}_{18} \mathrm{H}_{28} \mathrm{~N}_{2} \mathrm{O}$ Calcd.: 288.2202, found: 288.2209

\subsubsection{Synthesis of $N$-4-Benzonitrile Alkylamides}

Carboxylic acid (1.0 eq) was added, at $0{ }^{\circ} \mathrm{C}$ (ice bath) under $\mathrm{N}_{2}$ atm. with constant stirring, to 1.0 eq of DCC and 1.0 eq of 4-aminobenzonitrile dissolved in $\mathrm{CH}_{2} \mathrm{Cl}_{2}$. After $5 \mathrm{~min}$ the ice bath was withdrawn and the mixture was stirred (protected from light). The reaction was followed by TLC (silica gel and hexane:EtOAc 9:1). The reaction mixture was filtered and the solid washed with cooled $\mathrm{CH}_{2} \mathrm{Cl}_{2}$. The liquid phase was evaporated and the residue was purified by column chromatography over $\mathrm{SiO}_{2} / \mathrm{K}_{2} \mathrm{CO}_{3} 5 \%$ (gradient Hexane:EtOAc).

$N$-(4-Benzonitrile) hexylamide (17e). IR (KBr): $v=3324 \mathrm{~cm}^{-1}, 2220(\mathrm{CN}), 1681,840 ;{ }^{1} \mathrm{H}$ NMR $\left(\mathrm{CDCl}_{3}\right): \delta=9.26(\mathrm{~s}, 1 \mathrm{H}, \mathrm{NH}), 7.71\left(\mathrm{AA}^{\prime} \mathrm{BB}, 4 \mathrm{H}, \mathrm{Ph}\right), 2.46$ (t, 2H, H-8), 1.74 (m, 4H, H-9, H-10), 1.34 (m, 2H, H-11), 0.88 (t, 3-H, H-12); $\left.{ }^{13} \mathrm{C} \mathrm{NMR} \mathrm{(75.4} \mathrm{MHz,} \mathrm{CDCl}_{3}\right): \delta=172.7(\mathrm{C}=\mathrm{O}), 153.8$ (Cipso $\mathrm{NH}), 151.2$ (Cipso CN), 132.6 (Corto CN), 119.3 (Corto NH), 105.6 (CN), 37.0 (C-8), 30.9 (C-9), 
24.8 (C-10), 21.9 (C-11), 13.4 (C-12); MS (70 eV): $\mathrm{m} / \mathrm{z}(\%)=216 \quad(<2)\left[\mathrm{M}^{+}\right], 160$ (8) $\left[\mathrm{CH}_{2} \mathrm{CONHC}_{6} \mathrm{H}_{4} \mathrm{CN}+\mathrm{H}^{+}\right], 118(100)\left[\mathrm{NHC}_{6} \mathrm{H}_{4} \mathrm{CN}\right]$.

$N$-(4-Benzonitrile) nonamide (17f). m.p. $45-46{ }^{\circ} \mathrm{C}$ (hexane:AcOEt 8:2); IR (KBr): $v=3310 \mathrm{~cm}^{-1}$, 3185, 2926, 2221(CN), 1651(C=O), 843; ${ }^{1} \mathrm{H}$ NMR $\left(\mathrm{CDCl}_{3}\right): \delta=9.2($ br s, $1 \mathrm{H}, \mathrm{NH}), 7.68\left(\mathrm{AA}^{\prime} \mathrm{BB}\right.$ ', 4H, $\mathrm{Ph}$ ), 2.42 (t, 2H, $\mathrm{CH}_{2} \mathrm{CO}$ ), 1.73 (m, 2H, H-8), 1.27 (m, 10H, H-9, H-10, H-11, H-12, H-13, H-14), 0.87 $\left(\mathrm{t}, 3 \mathrm{H}, \mathrm{CH}_{3}\right) ;{ }^{13} \mathrm{C} \mathrm{NMR}\left(\mathrm{CDCl}_{3}\right): \delta=173.0(\mathrm{C}=\mathrm{O}), 153.9$ (Cipso $\left.\mathrm{CN}\right), 142.2$ (Cipso HNCO), 132.1 (Corto CN), 119.6 (Corto HNCO), 104.9 (CN), 36.7 (C-8), 32.0 (C-9), 28.4 (C-10), 28.2 (C-11), 25.8(C-12), 25.2 (C-13), $22.3 \quad$ (C-14), $13.7 \quad(\mathrm{C}-15) ; \quad \mathrm{MS} \quad(70 \mathrm{eV}): \mathrm{m} / \mathrm{z}(\%)=258 \quad$ (30) $\left[\mathrm{CH}_{2} \mathrm{CONC}_{6} \mathrm{H}_{4} \mathrm{CN}\right], 141(24)\left[\mathrm{C}_{9} \mathrm{H}_{17} \mathrm{CO}\right], 60$ (100) $\left[\mathrm{C}_{2} \mathrm{H}_{6} \mathrm{NO}\right]$.

\subsubsection{Synthesis of $N$-[4-Phenyl-(imidazo-2-yl)]-alkylamides}

$N$-(4-Benzonitrile) alkylamide (1.0 eq) in a pressure tube was added 1.0 eq of ethylenediamine and 1.0 eq of $\mathrm{CS}_{2}$. The mixture reaction was stirred and irradiated in a chemical MW oven at 100 Watts in a range $112-179{ }^{\circ} \mathrm{C}$ at $15 \mathrm{seg}$ intervals during $5.0 \mathrm{~min} 30 \mathrm{seg}$. The reaction mixture changed from a deep yellow to pale yellow color and was purified over neutral $\mathrm{Al}_{2} \mathrm{O}_{3}$ with a top layer of anh. sodium sulphite (gradient of Hexane:EtOAc and finally EtOH). The solvent was evaporated and the residue was recrystallized of acetone. The pure compounds were characterized.

$N$-[4-Phenyl-(imidazo-2-yl)]-hexylamide (18e). IR (KBr): $v=3358 \mathrm{~cm}^{-1}, 2937,2868,1678(\mathrm{C}=\mathrm{O})$, 848; ${ }^{1} \mathrm{H}$ NMR $\left(\mathrm{CDCl}_{3}\right): \delta=7.20\left(\mathrm{AA}^{\prime} \mathrm{BB}\right.$ ', 4H, Ph), 3.8 (s, 4H, NCH2CH2NH), 3.04 (t, 2H, H-2), 1.45 (m, 2H, H-3), 2.28 (m, 2H, H-4), 1.22 (m, 4H, H-5, H-6), 0.81 (t, 3H, H-7); ${ }^{13} \mathrm{C} \mathrm{NMR}\left(\mathrm{CDCl}_{3}\right)$ : $\delta=164.6(\mathrm{~N}=\mathrm{C}-\mathrm{NH}), 154.3($ Cipso $\mathrm{NHPh}), 131.0($ Corto $\mathrm{N}=\mathrm{C}-\mathrm{NH}), 112.0($ Cipso $\mathrm{N}=\mathrm{C}-\mathrm{NH}), 107.5$ (Corto NHPh), 44.3 (C-2), 31.5 (C-3), 28.8 (C-4), 26.7 (C-5), 22.5 (C-6), 14.4 (C-7); HRMS $=\mathrm{C}_{15} \mathrm{H}_{21} \mathrm{~N}_{3} \mathrm{O}$ Calcd.: 259.1685 found: 259.1683 .

$N$-[4-Phenyl-(imidazo-2-yl)]-nonamide (18f). m.p. 123-124 ${ }^{\circ} \mathrm{C}$ (acetone); IR (KBr): $v=3315 \mathrm{~cm}^{-1}$, 2924, 1671(C=O), 846; ${ }^{1} \mathrm{H}$ NMR $\left(\mathrm{CDCl}_{3}\right): \delta=10.38$ (s, 1H, CONH), 10.3 (br.s, $\left.1 \mathrm{H}, \mathrm{N}=\mathrm{C}-\mathrm{NH}\right), 7.83$ (AA', BB', 4H, Ph), 3.86 (s, 4H, $\left.\mathrm{CH}_{2} \mathrm{CH}_{2} \mathrm{NH}\right), 2.34$ (t, $\left.J=7 \mathrm{~Hz}, 2 \mathrm{H}, \mathrm{CH}_{2} \mathrm{CO}\right), 1.57,(\mathrm{~m}, 2 \mathrm{H}, \mathrm{H}-4), 1.27$ (m, 10H, H-5, H-6,H-7, H-8, H-9), 0.84 (t, $\left.J=7 \mathrm{~Hz}, 3 \mathrm{H}, \mathrm{CH}_{3}\right) ;{ }^{13} \mathrm{C} \mathrm{NMR}\left(\mathrm{CDCl}_{3}\right): \delta=172.6(\mathrm{C}=\mathrm{O})$, $164.4(\mathrm{~N}=\mathrm{C}-\mathrm{NH}), 144.4$ (Cipso $\mathrm{N}=\mathrm{C}-\mathrm{NH}), 129.7$ (Corto $\mathrm{N}=\mathrm{C}-\mathrm{NH}), 118.9$ (Corto $\mathrm{NCO}$ ), 118.5 (Cipso NCO), $46.0\left(=\mathrm{NCH}_{2} \mathrm{CH}_{2} \mathrm{NH}\right), 36.9$ (C-3), 31.7 (C-4), 29.2 (C-5), 29.1 (C-6), 29.0 (C-7), 25.4 (C-8), 22.5 (C-9), 14.4 (C-10) ; HRMS $=\mathrm{C}_{18} \mathrm{H}_{27} \mathrm{~N}_{3} \mathrm{O}$ Calcd.: 301.2154, found: 301.2153.

\subsection{Experimental Biological Section}

\subsubsection{Bacterial Strains}

Chromobacterium violaceum wt. ATCC 12472 and Serratia marcescens ATCC 8100 were generous gifts of Dr. Graciela Castro-Escarpulli and the ENCB Medical Bacteriology Laboratory respectively.

\subsubsection{Evaluation of the Effect of Bioisosteres on Cell Viability}

Cells from cultures exhibiting inhibition of pigment production in the presence of the imidazolines under study were washed by centrifugation and resuspended in the original volume of medium. Serial 
dilutions were spread onto Luria plates (C. violaceum) or tripticase soy agar plates (S. marcescens) and counted to determine the CFU per milliliter.

\subsubsection{Quantification of Violacein in Chromobacterium violaceum Wild Type}

A flask containing $30 \mathrm{~mL}$ of autoclaved BBL thioglycolate (Becton, Dickinson, USA), supplemented with $17 \mathrm{mM} \mathrm{MgCl} 2,26 \mathrm{mM} \mathrm{K}_{2} \mathrm{HPO}_{4}, 2.8 \mathrm{mM} \mathrm{K}_{2} \mathrm{SO}_{4}, 3 \mathrm{mg} / \mathrm{mL}$ L-methionine and $500 \mathrm{ng} / \mathrm{mL}$ vitamin B12 (all previously sterilized by Millipore filtration) for the optimum production of violacein, was inoculated with an overnight Chromobacterium violaceum culture up to an optical density (OD) of 0.1 at $720 \mathrm{~nm}$. Aliquots $(990 \mu \mathrm{L})$ of culture were placed in a $2 \mathrm{~mL}$ tube. Then $10 \mu \mathrm{L}$ of the compound to be tested was dissolved in sterile dimethyl sulphoxide and diluted with the culture until reaching final concentrations of $100 \mathrm{pM}, 1 \mathrm{nM}, 10 \mathrm{nM}, 100 \mathrm{nM}, 1 \mu \mathrm{M}, 10 \mu \mathrm{M}, 100 \mu \mathrm{M}$ and $1 \mathrm{mM}$. DMSO alone was added to the control tubes. All tubes were sealed with Lid Bac filters and incubated at $28{ }^{\circ} \mathrm{C}$ at $900 \mathrm{RPM}$ during $15 \mathrm{~h}$ in the Thermomixer R (Eppendorf, Germany). A $15 \mathrm{~h}$ period of incubation was selected as the most adequate to measure the effect of the compounds, in accordance to the results of the kinetics of violacein production.

The activity of the bioisosteres was expressed as a percentage of specific production (sp) of violacein (as shown below) in relation to the control tubes. Each experiment was performed 6 times and the results analyzed by a two way ANOVA test with Duncan correction.

Specific production ${ }_{\mathrm{Im}}=\mathrm{A}_{577} / \mathrm{A}_{720}=\mathrm{X}$

Mean sp of controls $=100 \%$

Percentage of imidazoline specific production $=100-\mathrm{X}$

\subsubsection{Quantification of Prodigiosin on Serratia marcescens ATCC 8100}

Trypticase soy medium ( $5 \mathrm{~mL}$ ) was inoculated with the Serratia marcescens ATCC 8100 strain. The culture was incubated at $37{ }^{\circ} \mathrm{C} / 24 \mathrm{~h}$ then adjusted to a value of one of absorbance in the spectrophotometer.

Blank control and seven concentrations $(100 \mu \mathrm{M}, 10 \mu \mathrm{M}, 1 \mu \mathrm{M}, 0.1 \mu \mathrm{M}, 0.01 \mathrm{nM}, 0.001 \mu \mathrm{M}$, $0.0001 \mu \mathrm{M})$ of the compound $N$-[4-phenyl-(imidazo-2-yl)]-nonamide were placed in 8 tubes. The tripticase medium was added to the tubes and these were incubated at $22{ }^{\circ} \mathrm{C}$ during $17 \mathrm{~h}$.

\subsubsection{Extraction and Quantification of Prodigiosin}

Aliquots with $500 \mu \mathrm{L}$ of each culture were transferred into Eppendorf tubes of $1.5 \mathrm{~mL}$. After this, $500 \mu \mathrm{L}$ of ethanol containing 4\% hydrochloric acid were added. Tubes were shaken intensively with vortex and then they were centrifuged in a microcentrifuge (Hermle Z233 M-2) at 15,000 rpm for $3 \mathrm{~min}$. Finally $400 \mu \mathrm{L}$ of the red supernatant (prodigiosin) were placed in flat-bottom microplate wells and suspension was read in an ELISA reader at $540 \mathrm{~nm}$. The O.D. was also determined in the ELISA reader at $600 \mathrm{~nm}$, placing $400 \mu \mathrm{L}$ of bacterial culture from each of the tubes in a microplate well.

Specific production of prodigiosin $=\left(\mathrm{A}_{540} / \mathrm{A}_{600}\right)$ 


\section{Conclusions}

Three novel non-classical bioisosteres of AHL, imidazoline derivatives 18a, 18e and 18f, were found to inhibit the production of violacein, strongly suggesting an antiquorum sensing effect in Chromobacterium violaceum. The conjugation established between the heteroatom placed at the para position of the phenyl ring and the imidazoline moiety was a determining factor of the activity shown by the assayed compounds. The lowest concentration giving antiquorum sensing activity on Chomobacterium violaceum was $1 \mathrm{nM}$ of the imidazoline conjugated with the nonanoyl group, $\mathbf{1 8 f}$. This compound was active at almost all tested concentrations. The highest $Q S$ inhibitory activity on C. violaceum shown by the test compounds was by imidazoline 18a at $100 \mu \mathrm{M}$, without affecting the growth of the bacteria. At higher concentrations this compound did show inhibitory activity on bacterial growth. Imidazoline $\mathbf{1 8 b}$ had no $Q S$ inhibitory effect on $C$. violaceum, but it had a bacteriostatic effect at $100 \mu \mathrm{M}$ and a bactericide effect at $1 \mathrm{mM}$. Finally, imidazoline 18f, when tested on Serratia marcescens, inhibited the production of prodigiosin at $10 \mu \mathrm{M}$ and $100 \mu \mathrm{M}$, which strongly suggests an antiquorum sensing effect.

\section{Acknowledgements}

We thank Gerardo Aparicio Ozores for his contribution in the evaluation of compound 18f on Serratia marcescens. We gratefully acknowledge the financial support provided for this work by CONACYT (Mexico) through Research Grant No. 90894, and by IPN through Research Grants: SIP 20100679, 20110945 and PAPIRI. MMS and ABC are thankful to Conacyt and to IPN for a graduate and PIFI scholarships.

\section{References and Notes}

1. Fleming, A. Penicillin. Presented at Nobel Lecture 1945, Sweden, 11 December 1945.

2. Raffa, R.B.; Iannuzzo, J.R.; Levine, D.R.; Saeid, K.K.; Schwartz, R.C.; Sucic, N.T.; Terleckyj, O.D.; Young, J.M. Bacterial communication ("Quorum Sensing”) via ligands and receptors: A novel pharmacologic target for the design of antibiotic drugs. J. Pharmacol. Exp. Ther. 2005, 312, 417-423 and references therein.

3. Shih, P.-Ch.; Wang, Ch.-T. Effects of quorum-sensing deficiency on Pseudomonas aeruginosa biofilm formation and antibiotic resistance. J. Antimicrob. Chemother. 2002, 49, 309-314.

4. Otero Casal, A.M.; Muñoz Crego, A.; Bernárdez Hermida, M.I.; Fábregas Casal, J. Quorum Sensing. El Lenguaje de las Bacterias (in Spanish); Editorial Acribia: Zaragoza, España, 2005.

5. Galloway, W.R.; Hodgkinson, J.T.; Bowden, S.D.; Welch, M.; Spring, D.R. Quorum Sensing in gram-negative bacteria: Small-molecule modulation of AHL and AI-2 Quorum Sensing pathways. Chem. Rev. 2011, 111, 28-67.

6. Blackwell, H.E.; Fuqua, C. Introduction to bacterial signals and chemical communication. Chem. Rev. 2011, 111, 1-3.

7. Quorum sensing is a word which consists of a Latin word "quorum" and a English word "sensing" but his origin is Latin; in consequence we consider all the term must be written in italics. 
8. Moreira, L.L.; Barreiro, E.J. Bioisosterism: A useful strategy for molecular modification and drug design. Curr. Med. Chem. 2005, 12, 23-49.

9. Patani, A.G.; LaVoie, J.E. Bioisosterism. A rational approach in drug design. Chem. Rev. 1996, 96, 3147-3176.

10. Persson, T.; Hansen, T.H.; Rasmussen, T.B.; Skindersø, M.E.; Givskov, M.; Nielsen, J. Rational design and synthesis of new Quorum-sensing inhibitors derived from acylated homoserine lactones and natural products from garlic. Org. Biomol. Chem. 2005, 3, 253-262.

11. Chen, G.; Swem, L.R.; Swem, D.L.; Stauff, D.L.; O’Loughlin, C.T.; Jeffrey, P.D.; Bassler, B.L.; Hughson, F.M. A strategy for antagonizing quorum sensing. Mol. Cell 2011, 42, 199-209.

12. Geske, G.D.; Wezeman, R.J.; Siegel, A.P.; Blackwell, H.E. Small molecule inhibitors of bacterial Quorum Sensing and biofilm formation. J. Am. Chem. Soc. 2005, 127, 12762-12763.

13. Geske, G.D.; O’Neill, J.C.; Miller, D.M.; Mattmann, M.E.; Blackwell, H.E. Modulation of bacterial Quorum Sensing with synthetic ligands: Systematic evaluation of $N$-Acylated homoserine lactones in multiple species and new insights into their mechanisms of action. J. Am. Chem. Soc. 2007, 129, 13613-13625.

14. Janssens, J.C.A.; Steenackers, H.; Metzger, K.; Daniels, R.; Ptacek, D.; Verhoeven, T.; Hermans, K.; Vanderleyden, J.; de Vos, D.E.; de Keersmaecker, S.C.J. Interference with the Quorum Sensing systems of Salmonella enterica serovar typhimurium: Possibilities and implications. Commun. Agric. Appl. Biol. Sci. 2007, 72, 35-39.

15. Tomohiro, M.; Toshitaka, S.; Kiyomi, T.; Masashi, K.; Norihiro, K.; Junichi, K.; Tsukasa, I. Inhibition of quorum sensing in Serratia marcescens AS-1 by synthetic analogs of $\mathrm{N}$-Acylhomoserine lactone. Appl. Environ. Microbiol. 2007, 6339-6344.

16. Smith, K.M.; Yigong, B.; Suga, H. Induction and inhibition of Pseudomonas aeruginosa Quorum Sensing by synthetic autoinducer analogs. Chem. Biol. 2003, 10, 81-89.

17. Janssens, J.C.A.; Metzger, K.; Daniels, R.; Ptacek, D.; Verhoeven, T.; Habel, L.W.; Vanderleyden, J.; de Vos, D.E.; de Keersmaecker, S.C. Synthesis of $N$-acyl homoserine lactone analogs reveals strong activators of SdiA, the salmonella enterica serovar typhimurium LuxR homolog. Appl. Environ. Microbiol. 2007, 73, 535-544.

18. Smith, K.M.; Bu, Y.; Suga, H. Library screening for synthetic agonists and antagonists of a Pseudomonas aeruginosa autoinducer. Chem. Biol. 2003, 10, 563-571.

19. Yang, L.; Rybtke, M.T.; Jakobsen, T.H.; Hentzer, M.; Bjarnsholt, T.; Givskov, M.; Tolker-Nielsen, T. Computer-aided identification of recognized drugs as Pseudomonas aeruginosa Quorum Sensing inhibitors. Antimicrob. Agents Chemother. 2009, 53, 2432-2443.

20. Müh, U.; Schuster, M.; Heim, R.; Singh, A.; Olson, E.R.; Greenberg, P.E. Novel Pseudomonas aeruginosa Quorum-sensing inhibitors identified in an ultra-high-throughput screen. Antimicrob. Agents Chemother. 2006, 50, 3674-3679.

21. Zhu, H.; Sun, S.J. Inhibition of bacterial quorum sensing regulated behaviors by Tremella fuciformis extract. Curr. Microbiol. 2008, 57, 418-422.

22. Nagy, M.M. Quorum Sensing Inhibitory Activities of Various Folk-Medicinal Plants and the Thyme-tetracycline Effect. Biology Dissertations, Georgia State University, 2010, Paper 90. Available online: http://digitalarchive.gsu.edu/biology_diss/90 (accessed on 11 January 2012).

23. Mueh, U.; Hare, B.J.; Duerkop, B.A.; Schuster, M.; Hanzelka, B.L.; Heim, R.; Olson, E.R.; Greenberg, P.E. A structurally unrelated mimic of a Pseudomonas aeruginosa Acyl-homoserine lactone Quorum-sensing signal. Proc. Natl. Acad. Sci. USA 2006, 103, 16948-16952. 
24. Tomohiro, M.; Masashi, K.; Katsumasa, F.; Norihiro, K.; Tsukasa, I. N-Acylhomoserine lactone regulates violacein production in Chromobacterium violaceum type strain ATCC 12472. FEMS Microbiol. Lett. 2008, 279, 124-130.

25. Cristóbal, D.G. Síntesis de N,N-bis-[4'(2-bromo etoxi)benciliden] etilendiamina y su posible aplicación como monómero de supramoléculas, Tesis Profesional, ENCB-IPN, Mexico, 2007.

26. Gelens, E.; Smeets, L.; Sliedregt, L.A.J.M.; van Steen, B.J.; Kruse, Ch.G.; Leurs, R.; Orru, R.V.A. An atom efficient and solvent-free synthesis of structurally diverse amides using microwave. Tetrahedron Lett. 2005, 46, 3751-3754.

27. Partridge, M.W.; Turner, H.A. Derivatives of $n$-Hexyl phenyl ether as antituberculous compounds. J. Pharm. Pharmacol. 1953, 5, 111-116.

28. Harfenist, M.; Soroko, F.E.; McKenzie, G.M. 2-(Alkoxyaryl)-2-imidazoline monoamine oxidase inhibitors with antidepressant activity. J. Med. Chem. 1978, 21, 405-409.

29. Fujioka, H.; Murai, K.; Kubo, O.; Ohbay, Y.; Kita, Y. One-pot synthesis of imidazolines from aldehydes: Detailed study about solvents and substrates. Tetrahedron 2007, 63, 638-643.

30. Pathan, M.Y.; Paike, V.V.; Pachmase, P.R.; More, S.P.; Ardhapure, S.S.; Pawar, R.P. Microwave-assisted facile Synthesis of 2-substituted 2-imidazolines. ARKIVOC 2006, 205-210.

31. Pez, D.; Leal, I.; Zuccotto, F.; Boussard, C.; Brun, R.; Croft, S.L.; Yardley, V.; Ruiz L.M.P.; Gonzalez, D.P.; Gilberta, I.H. 2,4-Diaminopyrimidines as inhibitors of leishmanial and trypanosomal dihydrofolate reductase. Bioorg. Med. Chem. 2003, 11, 4693-4711.

32. Sing, B.; Pandey, A. Synthesis, characterization and mesomorphic properties of unsymmetrical $N$-( $O$-hydroxybenzylidene)- $N$-(4- $n$-alkoxybenzylidene) azines and their copper(II) complexes. Mol. Cryst. Liq. Cryst. 2010, 37, 57-67.

33. Martinelli, D.; Grossmann, G.; Séquin, U.; Brandl, H.; Bachofen, R. Effects of natural and chemically synthesized furanones on Quorum Sensing in Chromobacterium violaceum. BMC Microbiol. 2004, 4, 25.

34. McClean, K.H.; Winson, M.K.; Fish, L.; Taylor, A.; Chhabra, S.R.; Camara, M.; Daykin, M.; Lamb, J.H.; Swift, S.; Bycroft, B.W.; et al. Quorum Sensing and Chromobacterium violaceum: Exploitation of violacein production and inhibition for the detection of $\mathrm{N}$-acyl homoserine lactones. Microbiology 1997, 143, 3703-3711.

35. Mall, T.; Follath, F.; Salfinger, M.; Ritz, R.; Reber, H. Moxalactam in nosocomial infections with Serratia marcescens. Intensive Care Med. 1985, 11, 179-183.

36. Horng, Y.-T.; Deng, S.-C.; Daykin, M.; Soo, P.-C.; Wei, J.-R.; Luh, K.-T.; Ho, S.-W.; Swift, S.; Lai, H.-C.; Williams, P. The LuxR family protein SpnR functions as a negative regulator of $N$-acylhomoserine lactone-dependent Quorum Sensing in Serratia marcescens. Mol. Microbiol. 2002, 6, 1655-1671.

(C) 2012 by the authors; licensee MDPI, Basel, Switzerland. This article is an open access article distributed under the terms and conditions of the Creative Commons Attribution license (http://creativecommons.org/licenses/by/3.0/). 